\title{
Island tourism during the global economic crisis
}

\begin{abstract}
The purpose of this article was to observe the relationship between the tourism movement and the economic development of island territories during the global economic crisis (2008-2010). The aim of the paper was also answer the questions: why did some island territories react differently to the global economic crisis and if the coefficient of variation is a good indicator for assessing the changes in tourism movement during crisis events. Countries that have larger tourism expenditures as a proportion of GDP had a weak relationship between changes in tourist arrivals and changes in GDP. The islands prone to the global economic crisis did not have a stronger correlation between changes in tourist arrivals and GDP. The coefficient of variation was a good measure to indicate the island regions that were characterized by major changes in the volume of tourist movements.
\end{abstract}

Keywords

Global economic crisis • Tourism economic development • Tourism island territories $\cdot$ Tourism economy $\cdot$ Tourist movement

(C) University of Warsaw - Faculty of Geography and Regional Studies

\section{Katarzyna Podhorodecka}

Department of World Regional Geography Institute of Regional and Global Studies Faculty of Geography and Regional Studies University of Warsaw, Poland e-mail:kpodhorodecka@uw.edu.pl

\section{Introduction}

Tourism development has become the driving force in economic growth for many regions of the world - especially small economies that are not competitive in other sectors but have adequate environmental conditions to enable them to increase their expansion in the tourism market. According to L. Dwyer, D. Edwards, N. Mistils, C. Roman, and N. Scott (2009), major competition occurs within tourism industries worldwide, and also between destinations. Additionally, there is huge competition between new tourist destinations and those that are well-known. An analysis of the situation in specific countries and dependent territories during the period of the global economic crisis (2008-2010) showed that their situations varied. Some of these, despite the recession in the tourism market, obtained better results in the tourism sector than other areas which saw tourism-conditioned development. Developmental potential during the global economic crisis was fully applied in certain countries and dependent territories, while in others it was partially wasted. A detailed analysis will be conducted of selected countries and dependent territories whose economies reacted differently to the prevailing economic situation - the global economic crisis - as a result of their natural, cultural and political conditions. The present paper focuses on tourism-dependent countries (with more than $10 \%$ of GDP coming from international tourism). Fifteen island territories with varied policies on tourism and different social and cultural conditions were chosen for the analysis. An attempt is made to point out the conditions that led to a greater success in tourism development during the global economic crisis.

Island territories usually attract tourists who want to spend their holidays on the beach. Sometimes, the ability to do snorkelling, diving, or other sporting activities such as surfing, windsurfing and kitesurfing is also important. Islands are not only connected with the "three-S" type of tourism - "sea, sun, and sand" - but also with the "ten-S" type - "sea, sand, scenery, sun, surf, shopping, safety, sex, sincerity, and sociability." These letters show the possibilities when spending holidays on tropical islands (Crocombe 2001; Jędrusik 2005a; Jędrusik 2002).

It is incorrect to assume that the global economic crisis has ended, because in many parts of the world it initiated longterm recessions (Saruşik, Sari, Sari \& Halis 2011), especially in the labour market (Junankar 2011). Some opinions state that the tourism industry ${ }^{1}$ has no problem with a "double-dip recession" (Reddyis 2013) - especially tourism in the European, Asian and Pacific regions. It can also be observed that the global tourism economy has had a long-term average increase of 3-4\%, except during crisis events such as the Asian financial crisis in 1997, the terrorist attacks in September 2001, and the Asian tsunami in 2004. Moreover, the global tourism movement had reached enormous numbers - more than one billion foreign tourist arrivals in 2012.

${ }^{1}$ In this article, the WTTC definition for 'the tourism industry' was used, i.e. spending on "travel and tourism by residents and non-residents for business and leisure purposes as well as government individual spending." The characteristic sectors of the tourism industry include "hotels, airlines, airports, travel agents and leisure and recreation services that deal directly with tourists" (Travel \& Tourism 2013). The 'tourism economy,' according to the WTTC, is defined as: expenditures not only strictly connected with tourism, but also the expenditures by visitors on transport, food, fuel, and insurance. "The indirect effects of the influence of tourism come from the activity of other branches not strictly connected with tourism (e.g. construction, agriculture)" (Travel \& Tourism 2013) 
Tourism is regarded as the main economic sector for Small Island Developing States (SIDS), also called the blue economy. ${ }^{2}$ Nowadays, many island territories are strictly reliant on tourism (e.g. the Maldives, the Seychelles, Saint Lucia) (Jędrusik 2005b). For many of them, tourism is the main source of export. The strategy documents of island countries and dependencies include many sentences confirming that tourism has a positive impact on the local economy; moreover, it is also underlined that tourism is important in accelerating GDP increases in this area (Reddyis 2013). P. F. Wilkinson (1989) researched strategies for tourism in island microstates; in his opinion, island microstates should search for alternative forms of economic development, and tourism is the most suitable way.

\section{Literature Discussion}

Tourism has a great impact on economic activity, and tourism development is usually seen as profitable (Dwyer \& Forsyth 1993). It is very important to estimate the profits due to tourism and the conditions for increasing tourism expenditure (Fletcher 1994; Crompton, Lee \& Shuster 2001; Dwyer et al. 2004). Moreover, tourism brings in additional activity and also an increase in the tourism multiplier effect. C. Lim (1999) presented links between tourism development and macroeconomic indicators; the measures analysed were revenues, the cost of transportation, and tourism prices. J. Coshall (2000) analysed tourism expenditures according to currency exchange rates, while $S$. Vanegas and R. Croes (2000) produced an econometric model connected with the number of tourist arrivals in Aruba. The impact of tourist arrivals on the economic growth of the Cayman Islands was analysed by K. Podhorodecka (2014). A. G. Webber (2001) investigated popular tourist locations suitable for a long-term demand in tourism (Wang 2009, after Webber 2001). S. Wanhill (1994) checked the measurement of tourist income multipliers.

The impact of the tourism movement and tourism expenditure on island economies was researched by H. W. Armstrong and R. Read (2000); G. Bertram and B. Poirine (2007); R. Shareef, S. Hoti and M. McAleer (2008); and J. L. McElroy and C. E. Perri (2010).

In many analyses, events are highlighted that make such a relationship weaker. These events include such things as terrorist attacks, economic crises, restrictive visa regulations and natural disasters (e.g. tsunamis and earthquakes). Much of the literature focuses on the impact of crisis events on tourism (Ryan 1993), as demonstrated by the following articles. B. Prideaux and S. Witt (2000) demonstrated the impact of the Asian financial crisis on Australian tourism. There are many examples of decreases in tourist movement due to the events of September 11, 2001 (Blake, Sinclair 2003, p. 823; Chu 2008; Goodrich 2001) and natural disasters (Kim, Chen \& Jang 2006). Additionally, J. H. Huang and J. C. H. Min (2002) analysed the terrorist attacks and earthquake in Taiwan (Wang 2009 after Huang \& Min 2002); meanwhile, an analysis by A. Pizam and A. Fleischer (2002) shows the impact of acts of terrorism on the demand for tourism.

Tourism is very fragile when it comes to fluctuations in the global market and bad cyclical factors can result in a decrease in tourism consumption; this is connected with a drop in the number of people employed in the tourist industry and, therefore, the creation of unemployment. Many consumers of tourism make individual decisions and prefer closer destinations, mainly domestic destinations or foreign destinations in neighbouring countries. Tourists also cut their expenditure and prefer cheaper accommodation. Crises have long-term and negative impacts on economies and result in a decrease in demand and in the revenues of enterprises. There is a need to cut investment plans because costs are greater. Crisis events result in very

${ }^{2}$ Malta and Cyprus are not classified as SIDS. stressful living and working conditions for local people, although such situations can sometimes provide positive results, such as the chance to produce new products, new markets, new management programmes or new ideas on how to cut costs (Okumus \& Karamustafa 2005). According to P. Flatters and M. Willmott, research conducted by the Monetary Fund, which analysed 122 recessions in 21 developed countries from 1960, showed that the typical recession saw a GDP decrease of about $2 \%$ and lasted one year (Flatters \& Willmott 2009)

A. Papatheodorou, J. Rosselló and H. Xiao (2010), wrote in 2010 that "domestic tourism is expected to boom" during the global economic crisis and cheaper travel, such as visiting friends and relatives or value-for-money destinations, would be preferred. Many crises have an impact on tourism. In recent years there have been many of these - September 11, 2001; terrorist attacks in some countries of North Africa; natural disasters; and the global economic crisis (Ritchie 2004).

For a full understanding of the impact of the global economic crisis, 'crisis' needs to be defined. The word crisis comes from the Greek word krisis, which means the differentiation of a decision, and it is used in various meanings. There is no universal definition of 'crisis', but many authors who define 'economic crisis' say that 'crisis' is connected with an unexpected situation or event that brings trouble and problems to the economy. The relevant decisions can minimize the effects of the crisis and lead to a better situation (Ghaderi, Mat Som \& Henderson 2012). The word crisis in the Chinese language comes from two words: danger and chance occasion. This means that, under the proper conditions, a crisis can lead to advantage (Askaldowicz-Figiel 2011). According to P. Kotler and J. Caslione (2009), the tourism sector within the global economy is affected by many crises, which should be the normal situation; then the tourism sector starts to understand how to react to crisis events (Zdon-Korzeniowska \& Rachwał 2011; Kotler \& Caslione 2009). Many crisis situations can be listed for tourism economies: natural disasters, terrorist attacks, and ethnic conflicts, all of which bring a decrease in foreign tourist arrivals (Shareef \& McAleer 2005). The globalization of the tourism industry has meant a rapid increase in tourism's proportion of GDP for island countries.

The economic impact of tourism on SIDS is discussed by S. Pratt (2015), who estimated the economic contribution of tourism for seven SIDS. B. Seetanah (2011) analysed 19 island economies from 1990 to 2007 in order to check the contribution of tourism to economic development. R. Scheyvens and J. Momsen (2008) analysed the possibilities for poverty reduction in the case of small island states. S. F. Schubert., J. G. Brida and W. A. Risso (2011) also checked the impacts of international tourism on the development of small economies which were dependent on tourism. M. Jędrusik discussed sustainable development on small tropical islands (2014). D. Rucińska and M. Lechowicz discussed the impact of natural hazard and disaster tourism (2014). J. L. McElroy and C. E. Parry (2010) also indicated specific small island tourist economies. During an economic crisis, territories usually attract tourists from countries with a better economic situation; such an example was confirmed by K. Podhorodecka (2016) in the case of Cyprus.

Crisis phenomena are the subject of research in many different areas of science, including political science, economics and social science. For each area of science there is a different definition of crisis (ed. Dziedzic 2012). A crisis is defined as an unplanned, unexpected event that comes from an external or internal source (e.g. the environment or an organization), which results in people being in fear (physically or mentally). This leads to a situation that is impossible to cope with under usual management procedures.

There are different categories of crises - for example, ecological, regional and global. Although different crises fall into different categories, they are connected; for example, ecological 
crises, wars, and terrorist attacks may result in political crises and those in turn result in a crisis in the tourism industry of the specific county. Some examples include the conflict in the Persian Gulf (in 1991), the war in the former Yugoslavia (beginning of the 1990s), the conflicts in the Middle East, the political problems in Tibet, the war in Iraq (in 2003; Okumus \& Karamustafa 2005), and the annexation of Crimea by Russia in 2014. According to E. Laws and B. Prideaux, "[a] crisis in tourism is an event that distracts the actions of tourism enterprises" (ed. Dziedzic 2012, p. 12). A few sentences can be cited from R. Winiarski and J. Zdebski's book entitled "Psychology of Tourism":

The tourist's sense of security is strengthened by the following factors: the country's stable political and economic situation, peaceful international politics, friendly people, environment protection and internal security, and having monitoring systems that allow the prediction of volcanic eruptions, earthquakes, typhoons, tsunamis, avalanches, floods, etc. In general it can be said that tourism is an extremely sensitive business and that the costs of guaranteeing the safety of tourists will gradually increase, making some destinations inaccessible to the average tourist. (Nowakowska 2011, after Winiarski \& Zdebski 2008). ${ }^{3}$

It is very important for enterprises to be able to develop a strategy during a crisis. Due to product innovation and processing innovation, it is possible to lower sales prices (Zdon-Korzeniowska \& Rachwał 2011, after Repetowski 2010). According to UNWTO data, the tourism industry saw an $8 \%$ decrease in 2009 compared to 2008 . The regions most affected by the crisis were the Middle East and Europe (with a decrease in tourist movement of $6 \%$ for 2008/2009) (Geise, 2009). North America was greatly affected (a decrease of $5 \%$ ), as was the Asia and Pacific region (Dziedzic et al. 2010; UNWTO World Tourism Barometer 2010). Decreases were recorded for large European countries such as France (a decrease of $3 \%$ ), Spain (a decrease of $9 \%$ ) and the United Kingdom (a decrease of $6 \%$ ), as well as the United States of America (a decrease of $5 \%$ ), for the same period of time (www.unwto.org). The airlines reacted very quickly to the crisis by decreasing the number of business tickets and increasing the number of economy ones (Geise 2009).

According to UNWTO data, the global economic crisis had a large impact on tourism, especially in 2009 , when a decrease in foreign tourist arrivals was recorded from 920 million to 880 million (a 4.3\% decrease compared to 2008). It was the biggest decrease of this indicator since UNWTO started collecting data about international tourism movements. The only region that did not record a decrease in 2009 was Africa (5\% increase compared to 2008). However, the biggest decreases in international tourist arrivals were recorded in Europe (a decrease of $5.6 \%$ compared to 2008), North America (a decrease of $5.1 \%$ compared to 2008), the Asia-Pacific region (a decrease of $2.3 \%$ compared to 2008), and the Middle East (a decrease of $5.6 \%$ compared to 2008) (Dziedzic, Łopaciński, Saja \& Szegiedewicz 2010; UNWTO World Tourism Barometer 2010).

The European market was responsible for almost $70 \%$ of the global decrease in foreign tourist arrivals. This was connected with a worsening of the economies of countries that were very active in the tourism economy. The global income from earnings from the tourism sector in 2009 was $8-8.5 \%$ lower. The International Airlines Transport Association announced that 2009 "was the worst year for civil aviation since the Second World War." The decrease was recorded in passenger transportation, and the outcomes for aviation enterprises were also weaker (Dziedzic, Łopaciński, Saja \& Szegiedewicz, 2010; IATA Financial Forecast, September 2009). During the crisis the outcomes for the aviation enterprises also recorded a decrease in the number of premium passengers. Moreover, many consumers have taken up a less wasteful lifestyle (more recycling, buying used goods, and a

${ }^{3}$ Author's translation greater interest in green consumerism) (Flatters \& Willmott 2009). The same situation is found in the tourism industry with more interest in camping sites shown during the crisis.

According to I. Yeoman (2011), the global economic crisis created a change in consumers' attitudes and behaviours towards luxury goods. The renting of luxury products instead of buying them is increasing (Yeoman 2011). This is also connected with the popularity of borrowing and sharing websites. After the crisis, consumers of luxury goods had a greater eco-awareness (op. cit.). Moreover, during the economic crisis, tourists were searching for bargains and looking for last minute offers, especially using specialized websites (e.g. grabaseat). Consumers considered price to be the most important factor during the global economic crisis. Online holiday planning allows the price and quality of tourist services to be controlled, and around half of internet users check prices online (Yeoman 2010).

Sustainable development on islands was studied by A. Law, T. DeLacy and M. McGrath (2016) in the case of Bali. R. V. Bianchi (2004) described the sustainable tourism initiatives on the Canary Islands. J. Capo, A. R. Font and J. R. Nadal (2007) found signs of Dutch disease on the Canary Islands similar to the reaction of a local economy to a rapid change in the export of natural resources. $R$. Buckley studied the linkages between surfing tourism and tourism development on Indo-Pacific islands (2002). J. C. Henderson (2000) researched the management of one of Singapore's islands, and R. Nunkoo, D. Gursoy and T. D. Juwaheer (2010) examined the relationship between tourism development and community for island economies. J. Kokkranikal, R. McLellan and T. Baum (2003) studied the Lakshadweep Islands and the link between tourism and sustainability development. A. Padilla and J. L. McElroy (2005) showed that the tourism penetration index is a universal measure of the economic, social and environmental impact on small islands. Positive development paths for sustainable tourism on small islands were presented by R. Scheyvens and J. Momsen (2008).

According to D. L. Edgell, A. M. DelMastro, G. Smith and J. P. Swanson (2008), it is important to understand the various definitions of "tourism sector" according to the World Tourism Organization (UNWTO), the World Travel and Tourism Council (WTTC), and the Organization of Economic Development and Cooperation (OECD): "Tourism is a service area spread over multiple subsector areas, with some exclusive to tourism and others inclusive of tourism" (the hospitality industry, food and beverage, airlines and campgrounds).

\section{Scientific Objective}

The first aim of this article is to answer the question: Which island territories show a strong positive correlation between change in the number of tourists visiting the territories and change in the GDP in particular years? The hypothesis is that island territories that have a very high level of tourism-dependency show a stronger correlation between changes in the number of foreign tourist visits and changes in GDP.

The second aim of the article is to answer the question: Why did some islands react differently to the global economic crisis (2008-2010) with respect to the number of tourist visits? It is assumed that island territories, which proved to be very prone to the global economic crisis, have a stronger correlation between changes in tourist arrivals and GDP.

The third aim of the article is to check the possibility of using the coefficient of variation to observe changes in tourism movement during crisis events. The hypothesis is that the coefficient of variation is a good measure for checking how fragile a tourism economy is in regard to external factors such as economic crises, natural disasters and so on, but the ratio does not show the direction of the changes. 


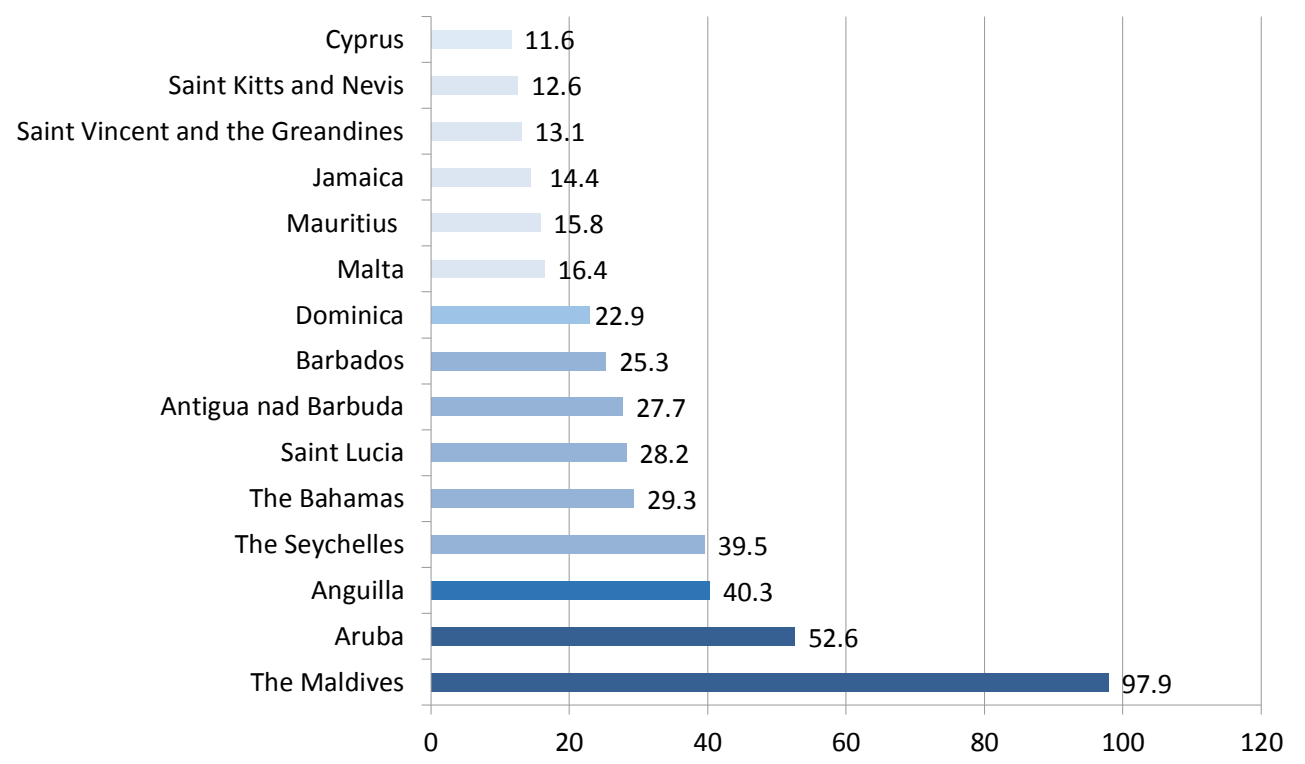

Figure 1. Selected island territories with more than 10\% of GDP coming from tourism expenditure in $2012 .{ }^{4}$ Source: author's calculations based on UNWTO data (www.unwto.org).

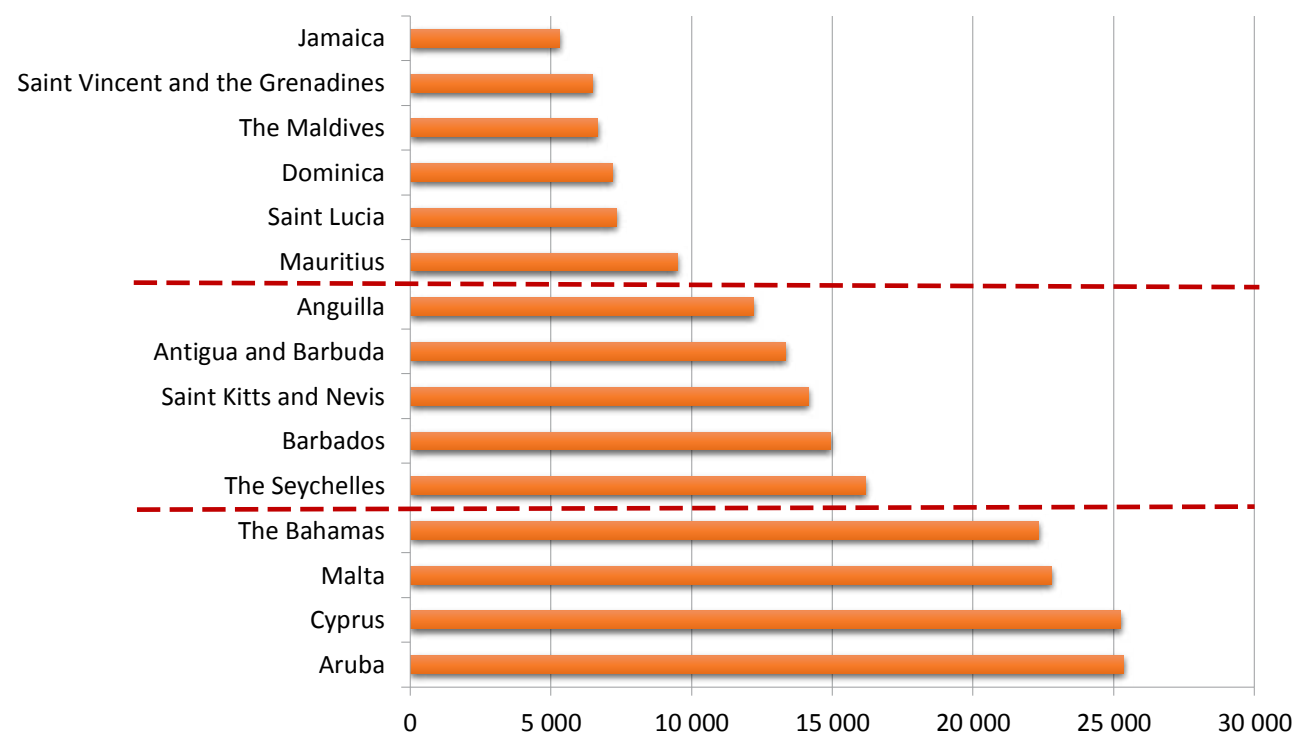

Figure 2. Gross domestic product per capita in 2012 for selected island territories. Source: author's calculations based on data from The World Bank Website 2014 (www.data.worldbank.org), www.indexmundi.com.

\section{Research Methods}

For the purposes of this work, indicators will be applied from the period 2000 to 2014 . The Spearman correlation method, the changeability ratio and the typology of tourist economies were used for the statistical data analysis. The measure of the level of development of a tourism-based economy was based on the number of incoming foreign tourists and one-day visitors. Additionally, the analysis included the inhabitants' quality of life, measured using the Human Development Index (HDI). In the statistical analysis, data about tourists' movements was obtained from the World Tourism Organization (UNWTO). Data about changes in GDP was acquired mainly from the World Bank Database, while data concerning the Human Development Index (HDI) came from the UN
Figure 1 presents the selected island territories that have more than $10 \%$ of their GDP coming from tourism expenditure for 2012. Figure 2 presents the gross domestic product per capita in 2012 for the selected island territories.

According to the HDI indicator, the analysed group can be divided into three categories: Group I - countries and dependent territories with a high HDI (more than 0.8). This group includes four island territories: Aruba (0.975), Anguilla (0.865), Cyprus $(0.845)$ and Malta (0.829). Group II - island territories with an average $\mathrm{HDI}$ ratio (from 0.75 to 0.8 ). This group includes six territories: the Bahamas (0.789), Barbados (0.776), Mauritius (0.771), Antigua and Barbuda (0.76), the Seychelles (0.756), and Saint Kitts and Nevis (0.75). Group III - island territories with the lowest HDI ratio (below 0.75). This includes five island territories: 


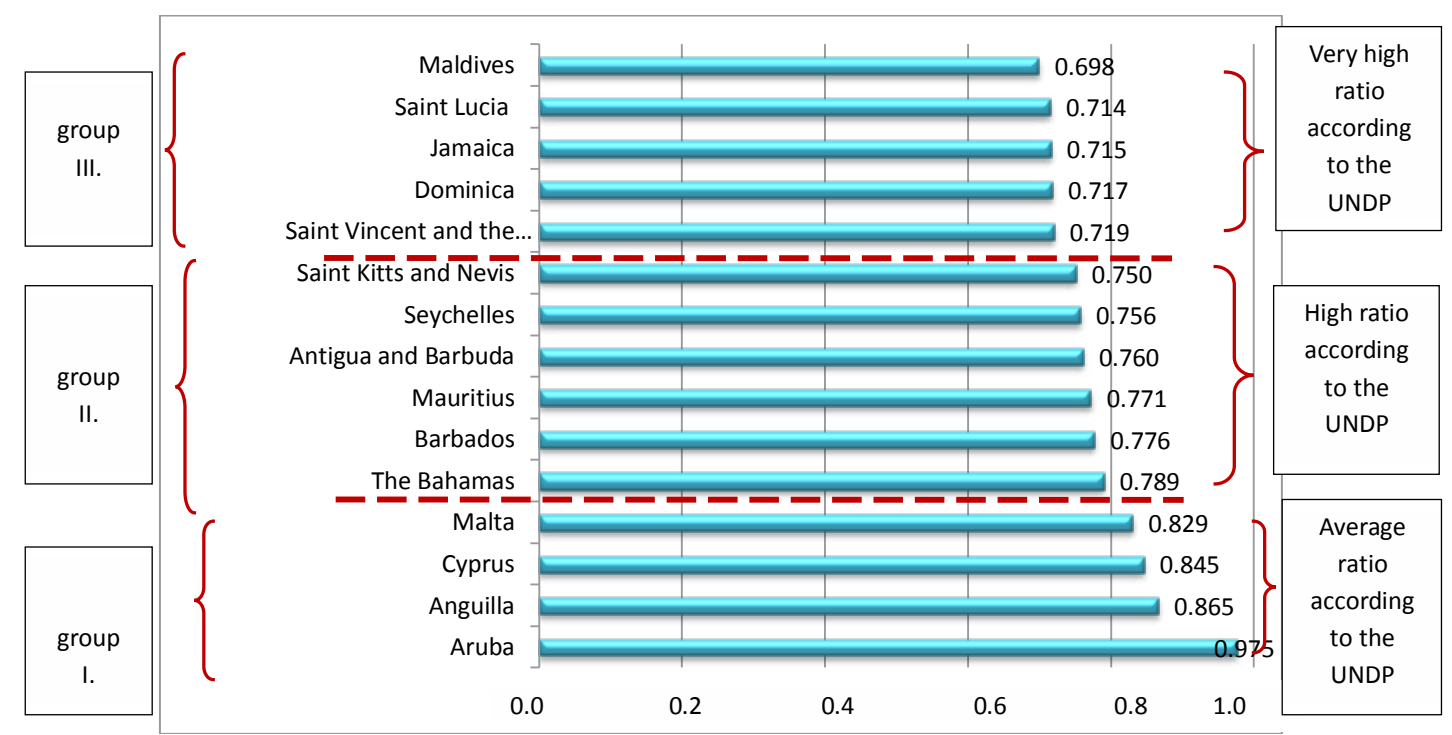

Figure 3. Human Development Index for selected island territories in 2013. Source: author's elaboration based on data from www.hdr. undp.org/en/data, http://hdr.undp.org/sites/default/files/Country-Profiles/ATG.pdf, Aruba - www.cbs.aw/index.php.

Table 1. Division of island territories according to the magnitude of the crisis in tourist and one-day visitor arrivals

\begin{tabular}{|c|c|c|c|c|}
\hline Type & $\begin{array}{l}\text { Change in tourist } \\
\text { arrivals 2011/2008 }\end{array}$ & $\begin{array}{l}\text { Magnitude of the crisis in tourist } \\
\text { and one-day visitor arrivals }\end{array}$ & Selected island territories & $\begin{array}{l}\text { Number of } \\
\text { countries }\end{array}$ \\
\hline A & $\begin{array}{l}\text { More than } \\
20 \% \\
\end{array}$ & $\begin{array}{c}\text { Island territories with no crisis in } \\
\text { tourist arrivals }\end{array}$ & $\begin{array}{c}\text { The Seychelles, the Bahamas, the } \\
\text { Maldives, Saint Kitts and Nevis }\end{array}$ & 4 \\
\hline B & $\begin{array}{c}\text { Between } \\
20 \% \text { and } 2 \%\end{array}$ & $\begin{array}{c}\text { Island territories with a small } \\
\text { decrease in tourist arrivals in } 2009, \\
\text { followed by an increase }\end{array}$ & Jamaica, Malta, Aruba, Saint Lucia & 4 \\
\hline $\mathrm{C}$ & $\begin{array}{c}\text { Between } \\
2 \% \text { and } 0 \%\end{array}$ & $\begin{array}{c}\text { Island territories that saw a } \\
\text { decrease in tourist arrivals, but } \\
\text { did not reach the levels of tourist } \\
\text { arrivals in } 2008\end{array}$ & Barbados, Mauritius, Cyprus & 3 \\
\hline $\mathrm{D}$ & $\begin{array}{l}\text { Decrease from } \\
17 \% \text { to } 2 \%\end{array}$ & $\begin{array}{l}\text { Island territories that saw a long- } \\
\text { term decrease in tourist arrivals }\end{array}$ & $\begin{array}{l}\text { Antigua and Barbuda, Anguilla, Dominica, } \\
\text { Saint Vincent and the Grenadines }\end{array}$ & 4 \\
\hline
\end{tabular}

Source: own elaboration.

Saint Vincent and the Grenadines (0.719), Dominica (0.717), Jamaica (0.715), Saint Lucia (0.714) and the Maldives (0.698).

According to the UNDP classification, countries with an HDI ratio of more than 0.89 are considered to be countries with a very high standard of quality of life. An HDI of $0.735-0.89$ describes countries with a high quality of life, while those with an HDI of $0.614-0.734$ are classified as countries with an average quality of life, and those below 0.493 are countries with a low quality of life (www.hdr.undp.org). According to these classifications, none of the territories analysed can be considered to be in the low quality of life group; however, one territory, Aruba, has a very high quality of life. The territories with a high quality of life are: Anguilla, Cyprus, Malta, the Bahamas, Barbados, Mauritius, Antigua and Barbuda, the Seychelles, and Saint Kitts and Nevis - a total of nine island territories. The territories with an average quality of life according to the UNDP classification are: Saint Vincent and the Grenadines, Dominica, Jamaica, Saint Lucia and the Maldives - a total of five island territories. The average HDI indicator for all the counties analysed using the UNDP classification was 0.702 (www.hdr.undp.org/en/data). For the small island territories mentioned above, the average indicator was 0.665 , while for lower developing countries it was 0.487 (www.hdr.undp.org). Figure 3 presents the Human Development Index for the analysed island territories for 2013.

The global economic crisis had very different impacts on the economies of the 15 analysed island territories. On the one hand, we can observe the very good results of the tourism economy for several island territories; but there were many islands that were negatively impacted for one or two years and later recorded an increase in tourist arrivals. However, there were island territories that had bigger problems with tourism development and their tourism economies experienced recessions (a decrease in tourism expenditures and a decrease in the number of jobs within the tourism economy).

Based on the changes in tourism movement, the island territories were divided into four groups: Type A countries and dependent territories with no crisis in tourist arrivals (Saint Kitts and Nevis, the Seychelles, Aruba); Type B countries where there was a small decrease in tourist arrivals in 2009 , followed by an increase - a better situation than in 2008 (the Bahamas and Malta); Type $\mathrm{C}$ island territories that saw a decrease in tourist arrivals but did not reach the levels of the 2008 situation (Cyprus, Jamaica, the

${ }^{4}$ The British Virgin Islands were not taken into account in the analysis because of the lack of data concerning GDP changes for 2000-2012. 
Table 2. Division of island territories according to crises connected with the number of tourist arrivals and divided according to the relationship of tourism expenditures as a proportion of GDP

\begin{tabular}{|c|c|c|c|c|}
\hline Type & $\begin{array}{c}\text { I - tourism expenditure is a } \\
\text { significant proportion of GDP } \\
\text { (from 10\% to 20\% of GDP) }\end{array}$ & $\begin{array}{c}\text { II - tourism expenditure is a } \\
\text { big proportion of GDP } \\
\text { (from 20.1\% to 40\%) }\end{array}$ & $\begin{array}{c}\text { III - tourism expenditure } \\
\text { is a very big proportion of } \\
\text { GDP (over 40\%) }\end{array}$ & $\begin{array}{c}\text { Number of } \\
\text { countries }\end{array}$ \\
\hline A & Saint Kitts and Nevis & The Seychelles, the Bahamas & The Maldives & 4 \\
\hline B & Jamaica, Malta & Saint Lucia & Aruba & 4 \\
\hline C & Mauritius, Cyprus & Barbados & Anguilla & 3 \\
\hline D & $\begin{array}{c}\text { Saint Vincent and the } \\
\text { Grenadines }\end{array}$ & $\begin{array}{c}\text { Antigua and Barbuda, } \\
\text { Dominica }\end{array}$ & 4 \\
\hline Total & 6 & 6 & 3 & 4 \\
\hline
\end{tabular}

Source: author's composition.

Table 3. Coefficient of variation for tourist and one-day visitor arrivals during the periods 2000-2013 and 2008-2012

\begin{tabular}{|c|c|c|c|}
\hline & Island territories & Coefficient of variation 2000-2013 & Coefficient of variation 2008-2012 \\
\hline 1 & Anguilla & $15 \%$ & $12.9 \%$ \\
\hline 2 & Antigua and Barbuda & $16 \%$ & $7.0 \%$ \\
\hline 3 & Aruba & $10 \%$ & $5.3 \%$ \\
\hline 4 & Barbados & $6 \%$ & $4.3 \%$ \\
\hline 5 & Cyprus & $4 \%$ & $4.4 \%$ \\
\hline 6 & Dominica & $29 \%$ & $19.7 \%$ \\
\hline 7 & Jamaica & $6.8 \%$ \\
\hline 8 & The Maldives & $14 \%$ & $15.7 \%$ \\
\hline 9 & Malta & $30 \%$ & $7.0 \%$ \\
\hline 10 & Mauritius & $18 \%$ & $3.5 \%$ \\
\hline 11 & Saint Kitts and Nevis & $15 \%$ & $18.4 \%$ \\
\hline 12 & Saint Lucia & $37 \%$ & $3.9 \%$ \\
\hline 13 & Saint Vincent and the Grenadines & $14 \%$ & $17.4 \%$ \\
\hline 14 & The Seychelles & $14 \%$ & $9.3 \%$ \\
\hline 15 & The Bahamas & $21 \%$ & $11.1 \%$ \\
\hline & Average for all island territories & $13 \%$ & $4.4 \%$ \\
\hline
\end{tabular}

Source: author's composition.

Maldives, Mauritius, Antigua and Barbuda); and Type D countries with a long-term decrease in tourist arrivals (Dominica, Barbados, Saint Vincent and the Grenadines, and Anguilla). Table 1 presents the division of island territories according to the magnitude of the crisis in tourist and one-day visitor arrivals.

Table 2 presents the division of island territories according to crises connected with the number of tourist arrivals and divided according to the relationship of tourism expenditures as a proportion of GDP.

Table 3 presents the coefficient of variation for tourist and one-day visitor arrivals during the periods 2000-2013 and 2008-2012, which will be of further use in assessing the effects of the global economic crisis on particular islands. The coefficient of variation was calculated as the quotient of the standard deviation and the average. The island territories with the largest coefficient of variation for 2000-2013 were: Saint Kitts and Nevis $(37 \%)$, the Maldives (30\%) and Dominica (29\%). However, the island territories with the largest coefficient of variation within the shortest period (i.e. closest to the global economic crisis, 2008-2012) were Dominica (19.7\%), Saint Kitts and Nevis $(18.4 \%)$ and Saint Vincent and the Grenadines (17.4\%).
The coefficient of variation rate allows the size of changes in the volume of tourist movement in a given year to be observed. However, it does not show trends, nor the direction in which the changes have taken place. Over the longer term - that is 2000-2013 - the rate is much higher than for the years in which the consequences of the global economic crisis were observed (2008-2012). The average variability rate for the analysed islands during the period $2000-2013$ was $11 \%$, while the average variability rate for the period $2008-2012$ was $4.4 \%$.

Below is the formula for the changeability ratio:

$V=\frac{s}{\bar{x}}, \quad \bar{x} \neq 0$

where: $s$ is the standard deviation and is the arithmetic average

The high coefficient of variation for tourist traffic to the Maldives during the period 2000-2013 was due to major changes in the number of tourist arrivals. Following the huge disaster caused by the tsunami in December 2004, the number of foreign arrivals to the Maldives recorded for 2005 decreased by as much as $35 \%$, while in 2006 an increase of $52 \%$ was recorded. 
Meanwhile, a very sharp decrease in the number of tourist arrivals was recorded in 2002 for the island of Saint Kitts and Nevis (decreasing by almost $30 \%$ due to the effects of the terrorist attacks in September 2001), but this fall was compensated for with a recorded increase in the number of tourists of approximately $55 \%$ in 2004 . Dominica was also characterized by a significant variability rate during the analysed period. In 2004, an increase of over $80 \%$ in the number of tourist arrivals was recorded, whereas a decrease of almost $20 \%$ occurred in 2005 , an increase of over $20 \%$ in 2006, and another increase of 30\% in 2009.

Meanwhile, for Saint Vincent and the Grenadines, the high coefficient of variation was due to a steep rise in the number of foreign tourists visiting the island in 2006 (almost $20 \%$ ), followed by a very sharp decline in the number of tourist arrivals in 2008 (almost $25 \%$ ) as a result of the global economic crisis. While the global economic crisis for European countries was recorded in tourism-related indicators in 2009 , for countries whose primary market was the United States (i.e. the islands of the Caribbean), the year was 2008. On Saint Vincent and the Grenadines, 2010 also proved to be an unfavourable year for tourism, with a decrease of $15 \%$ recorded in the number of tourist arrivals due to hurricane Tomas hitting the island at the end of October 2010. In summary, the coefficient of variation seems to be a good indicator for the islands that experienced a high variability in tourist movements during the analysed period. However, the ratio does not reflect the direction of change (decrease or increase). Large fluctuations in demand are very troublesome for the tourism industry due to the specifics of the sector. Difficulties within the sector include those associated with adjusting employment to suit fluctuating demand, as well as the inability to provide services on a larger scale (restrictions related to accommodation capacity and the high costs of accommodation development, as well as its maintenance). Thus, accommodation operators must be certain that an increase in demand is permanent rather than temporary - that it is associated solely with a short-term improvement in the economic situation - in order to make decisions about investments. In contrast, the group of countries and dependent territories in island regions with the lowest variability rate for the period 2000-2013 were Cyprus, Barbados and Aruba. Compared to other island regions, their fluctuations in tourism were not large at all, and were due to the general global trend towards reduced international travel in 2002 (a decrease of 10\%). The next decline in tourism demand in Cyprus occurred in 2010 (a decrease of $10 \%$ ), which also resulted from global factors, since the global economic crisis hit Europe a little later than Northern and Central America. Barbados is another island with a low variability rate. The largest decreases in this region occurred in 2005 (approx. 12\%) and 2012 (approx. 11\%). Barbados was hit by hurricane Tomas at the end of October 2010. Aruba is an example of an island that had the greatest increases in the number of foreign tourist arrivals for the years 2000 (almost 25\%), 2004 (10\%), 2008 $(10 \%)$ and $2013(12 \%)$. In further work, the Spearman correlation ratio was calculated for the changes in foreign tourist arrivals and the changes in GDP for the period 2000-2013 for specific islands (Table 4). The biggest correlations between changes in foreign tourist arrivals and changes in GDP during the period 2000-2013 were recorded in the Seychelles (0.686) and the Maldives (0.67). The lowest correlation was recorded for the Bahamas $(-0.119)$, Aruba (-0.095) and Saint Kitts and Nevis (0.125).

Below is the statistical data that was used for the calculation of the Spearman correlation ratio for particular islands (Fig 4).

The Spearman correlation for the relationship between the changes in foreign tourist arrivals and changes in GDP growth during the period 2000-2013 and the tourism expenditures as a proportion of the GDP (in \%) during the period 2000-2013 was -0.338 . The correlation was significant at the level of 0.05 .
Therefore, the hypothesis that island territories with a very high level of tourism dependency show a stronger correlation between changes in the number of foreign tourist visits and changes in GDP was not confirmed. The division of island territories according to crises connected with the number of tourist arrivals and divided according to the relationship of tourism expenditures as a proportion of GDP can be observed in table 5 . The Spearman correlation ratio for changes in foreign tourist arrivals and changes in GDP during the period $2000-2013$ was 0.232 , which means a low positive correlation.

After analysing the data concerning the division of the island territories according to the size of the crises in tourist and one-day visitor arrivals, the second hypothesis was also not confirmed. It has not been proved that island territories that were prone to the global economic crisis have a greater correlation between changes in tourist arrivals and GDP than islands with a bigger proportion of tourism in their economies (Table 6.).

\section{Conclusions}

This article indicated three types of tourism economies: Type I, countries and dependent territories that recorded tourism expenditures from $10 \%$ to $20 \%$ of GDP; Type II, island territories with a tourism expenditure proportion from $20.1 \%$ to $40 \%$ of GDP; and Type III, islands with a very large tourism expenditure as a proportion of GDP (over $40 \%$ ). The hypothesis that countries that have larger tourism expenditures as a proportion of GDP also have a strong relationship between changes in tourist arrivals and changes in GDP was only partially confirmed the Spearman correlation ratio was weak. Examples of countries and dependent territories for which such a relationship exists are as follows: Anguilla, the Maldives, the Seychelles, Antigua and Barbuda, Saint Kitts and Nevis, and Saint Lucia. Examples where there is no such relationship are Aruba and the Bahamas. This could be due to the fact that incidental events (natural disasters, crises and other incidents) may have resulted in a weaker correlation for particular years and these may also have influenced the GDP growth rate for the following year.

The second typology created in the article concerned the situation of island economies during the global economic crisis. Four types of tourism economy for island territories were indicated: Type A, island territories with no crisis in tourism arrivals; Type $B$, island territories with a small decrease in tourist arrivals in 2009, followed by an increase; Type C, island territories that saw a decrease in tourist arrivals, but did not reach the levels of tourist arrivals in 2008; and Type D, island territories that saw a long-term decrease in tourist arrivals. The article's second hypothesis was not confirmed because the island territories that were prone to the global economic crisis (Type A) usually did not record a correlation between changes in GDP and tourist arrivals (e.g. Aruba, Saint Kitts and Nevis). Also, several Type $D$ islands with a long-term decrease in tourist arrivals had an average or strong positive correlation between changes in GDP and tourist arrivals (e.g. Anguilla, Barbados). The article also uses the coefficient of variation to indicate the island regions that were characterized by major changes in the volume of tourist movements. In the group of islands with the highest changeability ratio, certain island regions recorded a decrease in tourism after 2009 and did not recover from the decreases of 2009 and 2010-2012 (e.g. Saint Vincent and the Grenadines, Dominica). These island regions belonged to Type $D$ categories. Of the islands with the lowest coefficient of variation for tourist movement, only Aruba belonged to Type A, the group of island regions that coped best with the aftermath of the global economic crisis. The coefficient of variation clearly reflects fluctuations in the level of tourist movement, but does not show the direction of change, and so the third hypothesis was confirmed. 

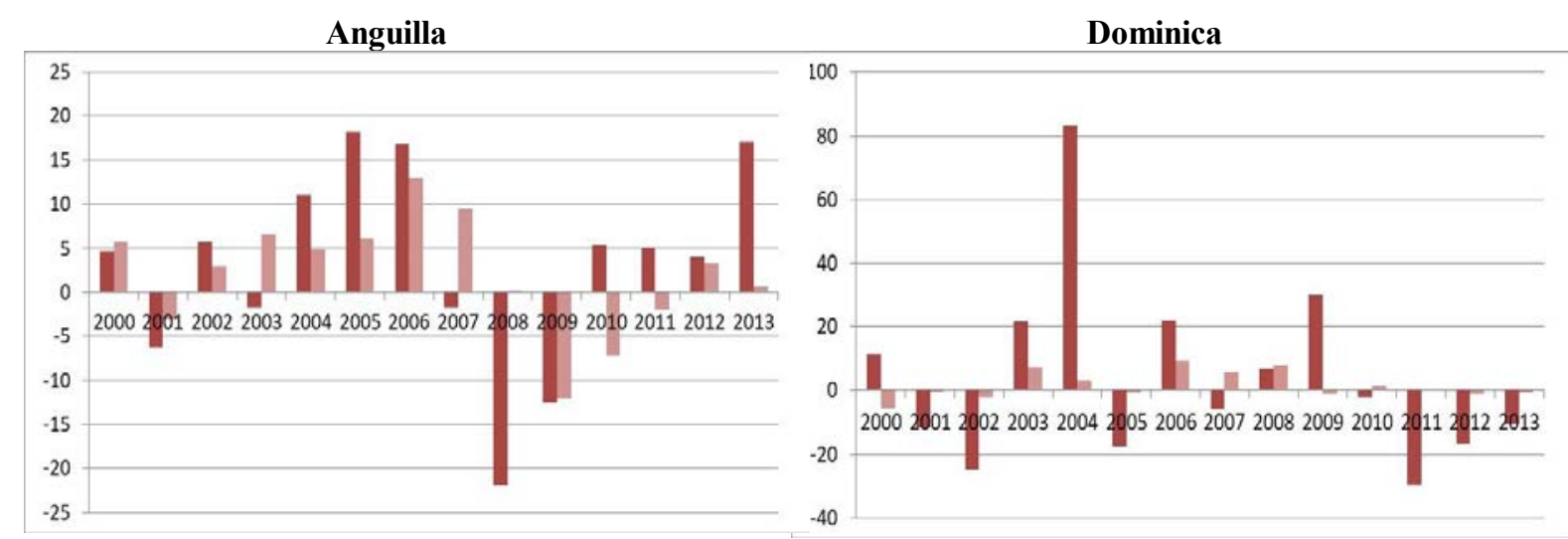

Antigua and Barbuda

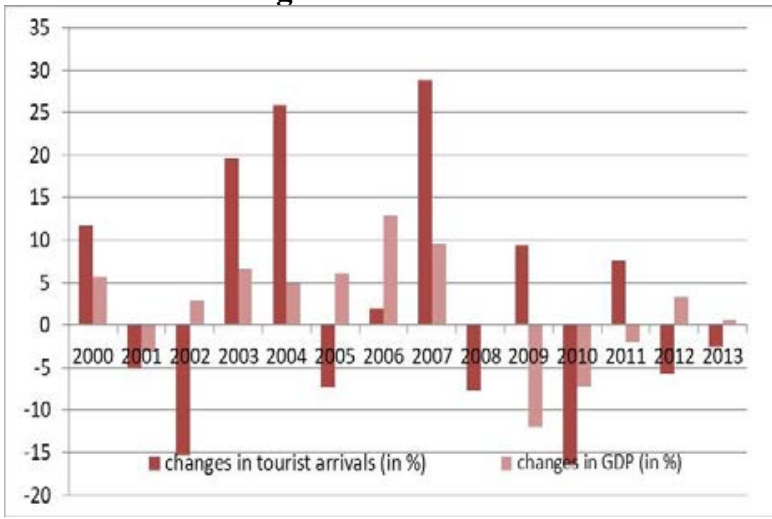

The Maldives
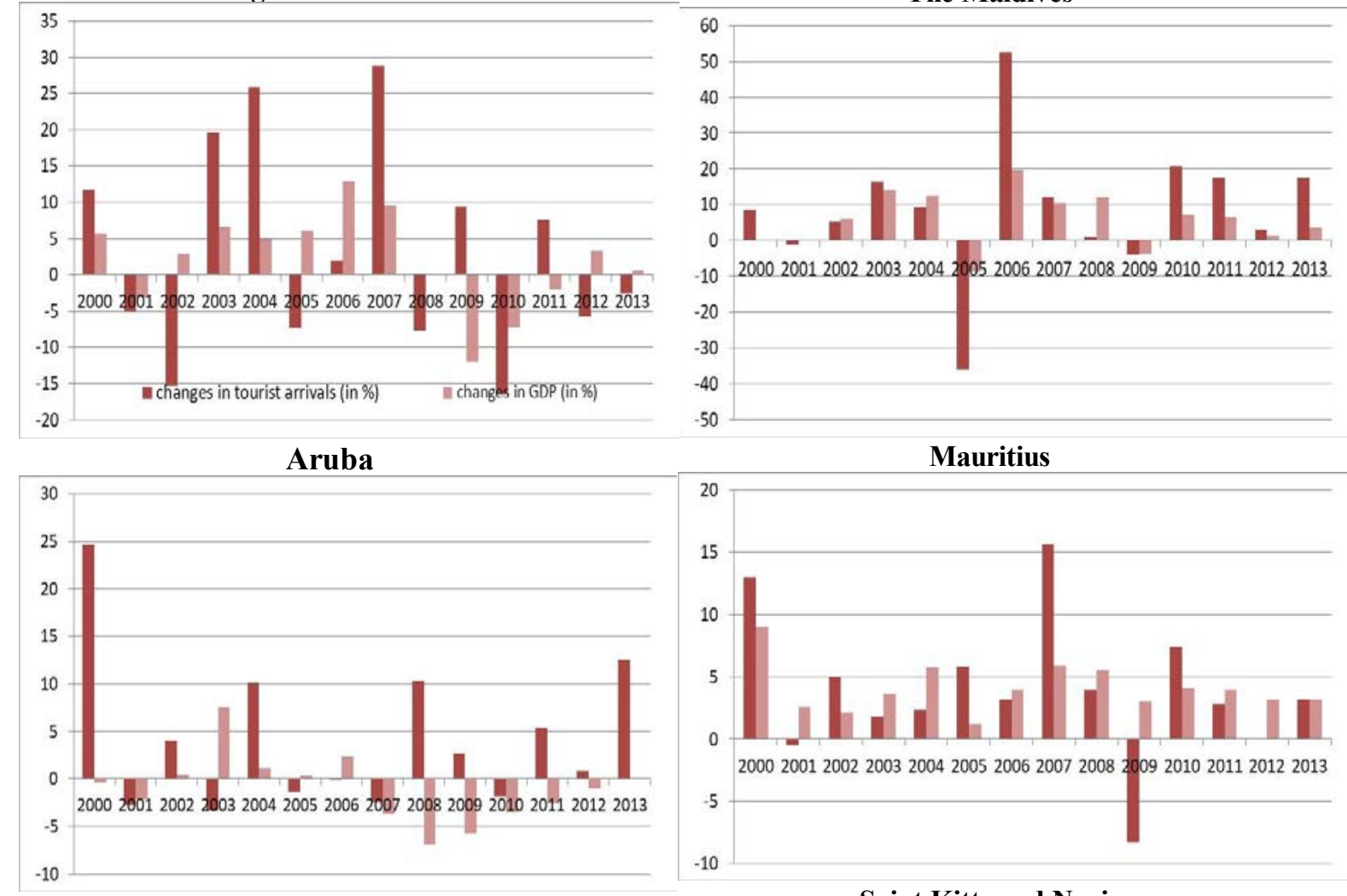

Barbados

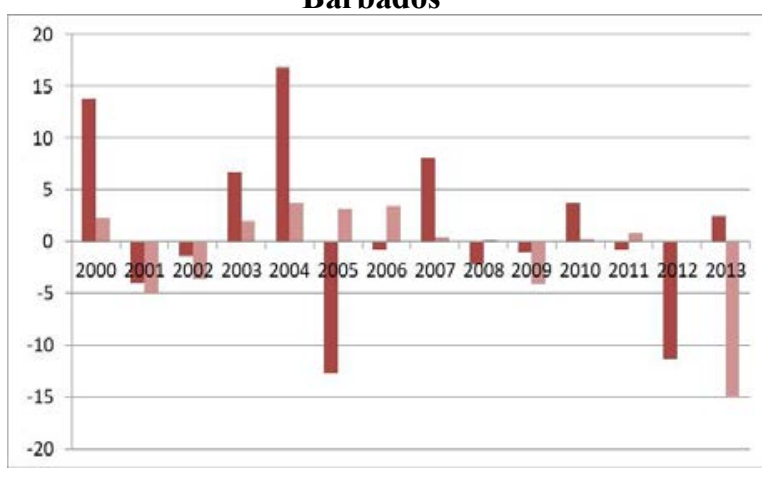

Saint Kitts and Nevis

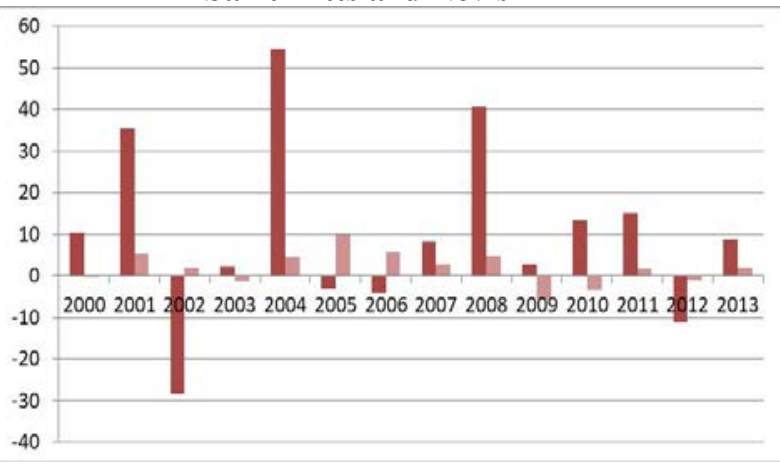

|- changes in tourist arrivals (in \%) $\|$ changes in GDP (in \%)

Figure 4. Changes in foreign tourist arrivals and changes in GDP growth for the period 2000-2013. Anguilla Statistics Department / ECCB, http://Www.gov.ai/statistics/NA_Publi_12.htm. Source: authors composition based on the UNWTO database, World Bank data and www.indexmundi.com. 
Saint Lucia

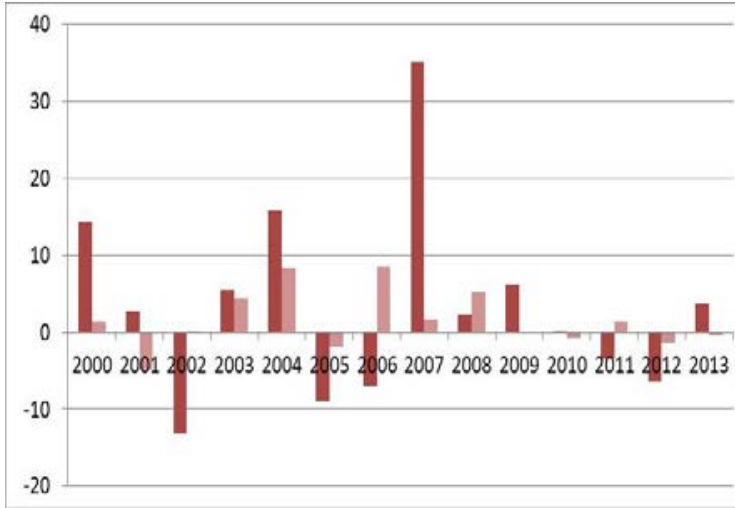

The Seychelles

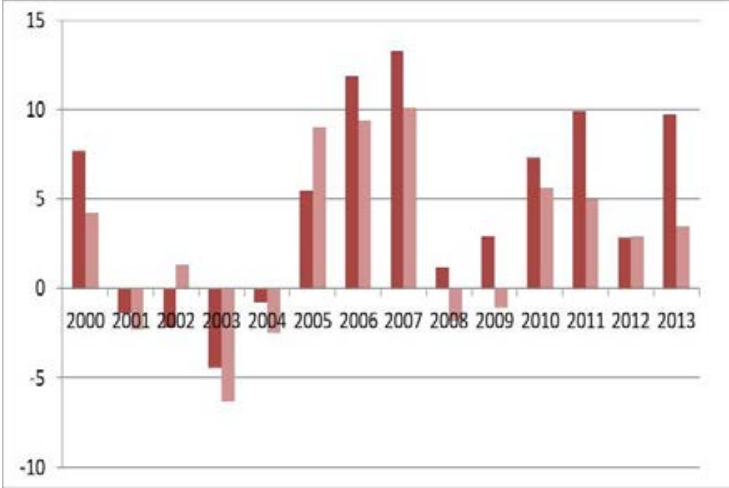

Saint Vincent and the Grenadines

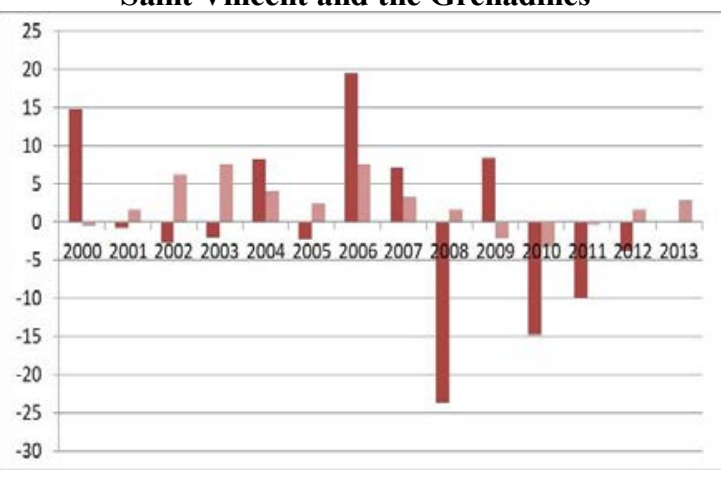

The Bahamas

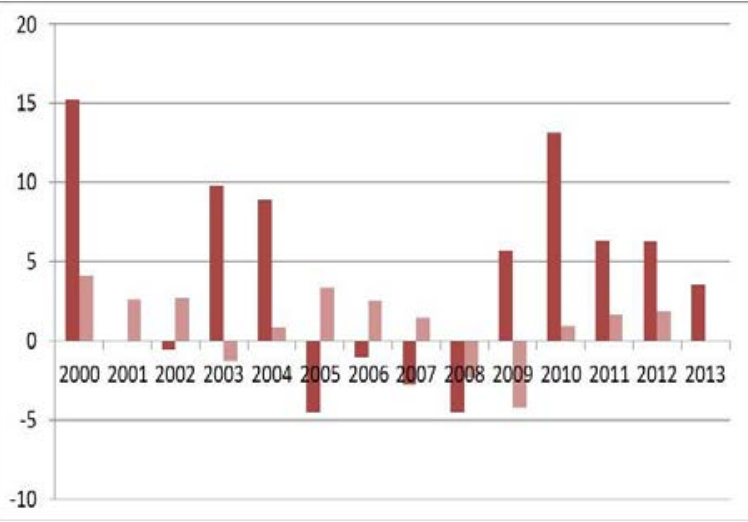

Malta

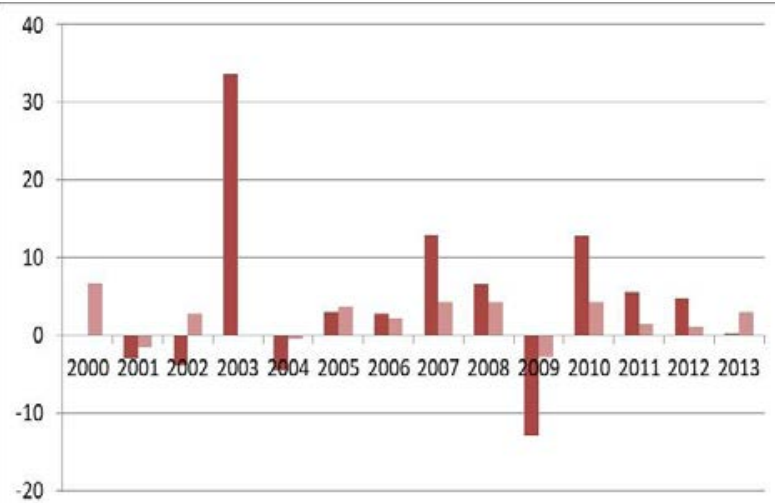

Cyprus

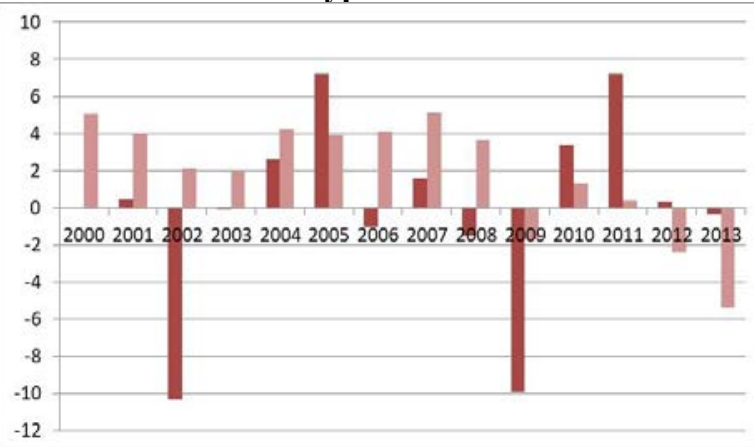

Jamaica

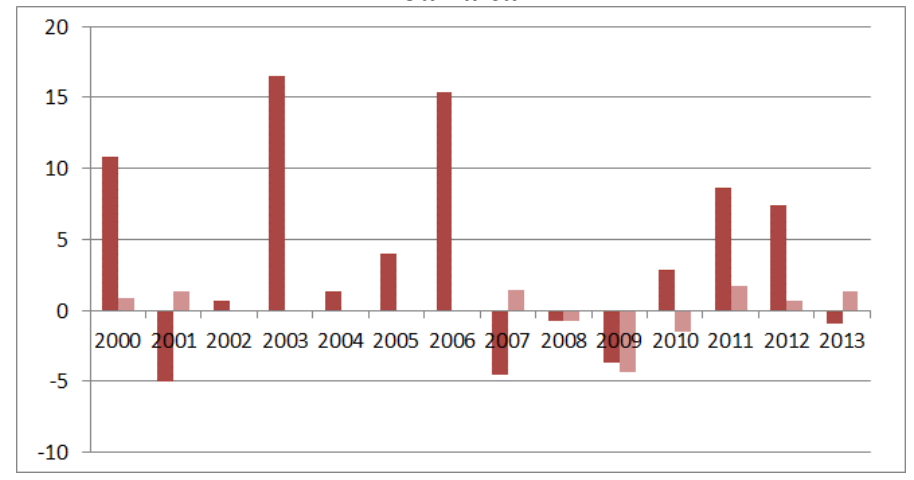

|

Continued Figure 4. Changes in foreign tourist arrivals and changes in GDP growth for the period 2000 2013. Anguilla Statistics Department /ECCB, http://www.gov.ai/statistics/NA_Publi_12.htm. Source: authors composition based on the UNWTO database, World Bank data and www.indexmundi.com. 
Table 4. Spearman correlation ratio between changes in foreign tourist arrivals and changes in GDP during the period $2000-2013$ (in \%)

\begin{tabular}{|c|c|c|c|}
\hline & Island territories & Spearman correlation ratio & Tourism expenditures as a proportion of GDP (in \%) \\
\hline 1 & Anguilla & 0.480 & 40.3 \\
\hline 2 & Antigua and Barbuda & 0.433 & 27.7 \\
\hline 3 & Aruba & -0.095 & 52.6 \\
\hline 4 & Barbados & 0.403 & 25.3 \\
\hline 5 & Cyprus & 0.336 & 11.6 \\
\hline 6 & Dominica & 0.378 & 22.9 \\
\hline 7 & Jamaica & 0.440 & 14.4 \\
\hline 8 & The Maldives & $0.670^{* *}$ & 97.9 \\
\hline 9 & Malta & 0.420 & 16.4 \\
\hline 10 & Mauritius & 0.438 & 15.8 \\
\hline 11 & Saint Kitts and Nevis & 0.125 & 12.6 \\
\hline 12 & Saint Lucia & 0.284 & 28.2 \\
\hline 13 & Saint Vincent and the Grenadines & 0.301 & 13.1 \\
\hline 14 & The Seychelles & $0.868^{* *}$ & 39.5 \\
\hline 15 & The Bahamas & -0.119 & 29.3 \\
\hline
\end{tabular}

** Correlation is significant at the level of 0.01 .

Source: own elaboration.

Table 5. Division of island territories according to crises connected with the number of tourist arrivals and divided according to the relationship of tourism expenditures as a proportion of GDP*

\begin{tabular}{|c|c|c|c|}
\hline Type & $\begin{array}{l}\text { I- tourism expenditure is a } \\
\text { significant proportion of GDP (from } \\
10 \% \text { to } 20 \% \text { of GDP) }\end{array}$ & $\begin{array}{l}\text { II - tourism expenditure is a big } \\
\text { proportion of GDP } \\
\text { (from } 20.1 \% \text { to } 40 \% \text { ) }\end{array}$ & $\begin{array}{c}\text { III - tourism expenditure is a } \\
\text { very big proportion of GDP } \\
\text { (over } 40 \%)\end{array}$ \\
\hline No correlation (3) & Saint Kitts and Nevis $(0.125)$ & The Bahamas $(-0.119)$ & Aruba $(-0.095)$ \\
\hline Weak correlation (4) & $\begin{array}{c}\text { Cyprus (0.336), Saint Vincent and the } \\
\text { Grenadines }(0.301)\end{array}$ & $\begin{array}{l}\text { Saint Lucia }(0.284) \\
\text { Dominica }(0.378)\end{array}$ & \\
\hline $\begin{array}{l}\text { Average or strong } \\
\text { positive correlation (8) }\end{array}$ & $\begin{array}{c}\text { Jamaica }(0.440), \text { Malta }(0.420) \\
\text { Mauritius }(0.438)\end{array}$ & $\begin{array}{c}\text { Barbados }(0.403) \text {, Antigua and } \\
\text { Barbuda }(0.433) \text {, the Seychelles } \\
(0.868)\end{array}$ & $\begin{array}{l}\text { Anguilla }(0.480) \text {, the Maldives } \\
(0.670)\end{array}$ \\
\hline Total (15) & 6 & 6 & 3 \\
\hline
\end{tabular}

*No correlation: below 0.2; weak correlation: greater than 0.2 but less than 0.4; average correlation: greater than 0.4 but less than 0.7 ; strong correlation: greater than 0.7 but less than 0.9; very strong correlation: greater than 0.9 (Ostasiewicz, Rusnak \& Siedlecka 1999). Source: author's composition.

Table 6. Division of island territories according to the size of the crisis in tourist and one-day visitor arrivals

\begin{tabular}{|c|c|c|c|c|c|}
\hline Type & $\begin{array}{c}\text { Number of } \\
\text { countries }\end{array}$ & $\begin{array}{c}\text { Size of the crisis in tourist and one-day } \\
\text { visitor arrivals }\end{array}$ & $\begin{array}{c}\text { No } \\
\text { correlation }\end{array}$ & $\begin{array}{c}\text { Weak } \\
\text { correlation }\end{array}$ & $\begin{array}{c}\text { Average or } \\
\text { strong positive } \\
\text { correlation }\end{array}$ \\
\hline A & 4 & $\begin{array}{c}\text { The Seychelles (0.868), the Bahamas (-0.119), Saint } \\
\text { Kitts and Nevis (0.125) the Maldives (0.670) }\end{array}$ & 2 & 0 & 2 \\
\hline B & 4 & Jamaica (0.440), Malta (0.420) Saint Lucia (0.284), \\
Aruba (-0,095) & 1 & 1 & 2 \\
\hline C & 3 & Mauritius (0.438), Cyprus (0.336) Barbados (0.403) & 0 & 1 & 2 \\
\hline D & 4 & $\begin{array}{c}\text { Saint Vincent and the Grenadines (0.301), Anguilla } \\
(0.480) \text { Antigua and Barbuda (0.433), Dominica (0.378) }\end{array}$ & 0 & 2 & 2 \\
\hline
\end{tabular}

Source: own elaboration. 
The limitations of the research include the fact that the article is based mainly on statistical analysis. Not all countries and dependent territories provide verified data to international organizations. Future research on this topic should indicate the conditions for the various reactions of particular countries and dependent territories to the global economic crisis. The implications of the research are that the use of the coefficient of variation for tourism purposes is appropriate, and the creation of the typology of island tourism economies during the global economic crisis can deliver knowledge about the conditions of the various reactions to crisis events.

\section{References}

Armstrong, HW \& Read, R 2000, 'Comparing the Economic Performance of Dependent Territories and Sovereign MicroStates', Economic Development and Cultural Change, vol. 48, pp. 285-306.

Askaldowicz-Figiel, M 2011, 'Znaczenie narzędzi marketingowych w działalności biur podróży w warunkach kryzysu, turystyki' in Turystyka Polsce w okresie kryzysu, eds A GotowtJeziorska \& K Łopaciński, Polskie Stowarzyszenie Turystyki, Warszawa, pp.117-142.

Bertram, G \& Poirine, B 2007, 'Island Political Economy' in A World of Islands: An Island Studies Reader, ed G Baldacchino, Institute of Island Studies and Agenda Academic, Canada and Malta, pp. 332-378.

Bianchi, RV 2004, 'Tourism restructuring and the politics of sustainability: a critical view from the European periphery (The Canary Islands)', Journal of Sustainable Tourism, vol. 12, no. 6, pp. 495-529.

Blake, A \& Sinclair, MT 2003, 'Tourism crisis management: US response to September 11', Annals of Tourism Research, vol. 30, no. 4, pp. 818-832.

Buckley, R 2002, 'Surf tourism and sustainable development in Indo-Pacific islands. The industry and the islands', Journal of Sustainable Tourism, vol. 10, no. 5, pp. 405-424.

Capó, J, Font, AR \& Nadal, JR 2007, 'Dutch disease in tourism economies: evidence from the Balearics and the Canary Islands', Journal of Sustainable Tourism, vol. 15, no. 6, pp. 615-627.

Central Bureau of Statistics of Aruba. Available from: <www.cbs. aw/index.php>. [12 December 2014].

Chu, FL 2008, 'A fractionally integrated autoregressive moving average approach to forecasting tourism demand', Tourism Management, vol. 29, no. 1, pp. 79-88.

Coshall, JT 2000, 'Spectral analysis of international tourism flows', Annals of Tourism Research, vol. 27, no. 3, pp. 577-589.

Crocombe, R 2001, The South Pacific, University of South Pacific, Suva.

Crompton, J, Lee, S \& Shuster, T 2001, 'A guide for undertaking economic impact studies: the Springfest example', Journal of Travel Research, vol. 40, no. 1, pp. 79-87.

Dwyer, L, Edwards, D, Mistils, N, Roman, C \& Scott, N 2009, 'Destination and enterprise management for a tourism future', Tourism Management, vol. 30, no 1, pp. 63-74.

Dwyer, L \& Forsyth, P 1993, 'Assessing the benefits and costs of inbound tourism', Annals of Tourism Research, vol. 20, no. 4, pp. 751-768.

Dwyer, L, Forsyth, P \& Spurr, R 2004, 'Evaluating tourism's economic effects: new and old approaches', Tourism Management, vol. 25, no. 3, pp. 307-317.

Dziedzic, E (ed.) 2012, Reagowanie branży turystycznej na sytuacje kryzysowe, Szkoła Główna Handlowa, Warszawa.

Dziedzic, T, Łopaciński, K, Saja, A \& Szegidewicz, J 2010, Polska gospodarka turystyczna w okresie światowego kryzysu, Instytut Turystyki, Polska Agencja Rozwoju Turystyki, Warszawa.

Edgell, DL, DelMastro, Allen, M, Smith, G \& Swanson, JP 2008, 'Tourism Policy and Planning', Yesterday, Today and Tomorrow, Butterworth-Heinemann, Amsterdam.
Flatters, P \& Willmott, M 2009, 'Understanding the PostRecession Consumer', Harvard Business Review, vol. 87 (7/8), pp. 106-112.

Fletcher, J 1994, 'Input-output analysis' in Tourism marketing and management handbook, eds S Witt \& L Moutinho, UK: Prentice-Hall International, pp. 480-484.

Geise, P 2009, 'Różne oblicza kryzysu w turystyce', Trendy $i$ tendencje, pp. 42-59.

Ghaderi, Z, Mat Som, AP \& Henderson, JC 2012, 'Tourism crises and island destinations: experiences in Penang, Malaysia', Tourism Management Perspectives, vol. 2-3, pp. 79-84

Goodrich, JN 2001, 'September 11, 2001 attack on America: a record of the immediate impacts and reactions in the USA travel and tourism industry', Tourism Management, vol. 23, no. 6 , pp. $573-580$.

Henderson, JC 2000, 'Managing tourism in small islands: the case of Pulau Ubin, Singapore', Journal of Sustainable Tourism, vol. 8 no. 3, pp. 250-262.

Huang, JH \& Min, JCH 2002, 'Earthquake devastation and recovery in tourism: the Taiwan case', Tourism Management, vol. 23 , pp. no. $2,145-154$.

Jędrusik, M 2002, 'Strategie i bariery rozwoju państw i terytoriów wyspiarskich na Oceanie Indyjskim', Afryka, Azja, Ameryka Łacińska, vol. 79, pp. 99-111.

Jędrusik, M 2005a, Wyspy tropikalne - w poszukiwaniu dobrobytu, Wydawnictwa Uniwersytetu Warszawskiego, Warszawa.

Jędrusik, M 2005b, 'Zasoby oceanów jako potencjał rozwojowy wysp tropikalnych', Czasopismo Geograficzne, vol. 76, no. 1-2, pp. 3-18.

Jędrusik, M 2014, 'The elusive sustainable development of small tropical islands', Miscellanea Geographica Regional Studies on Development, vol. 18, no. 3, pp. 26-30.

Junankar, NR 2011, 'The Global Economic Crisis: Long-Term Unemployment in the OECD', IZA Discussion Paper Series, no. 6057.

Kim, HY, Chen, MH \& Jang, SS 2006, 'Tourism expansion and economic development: the case of Taiwan', Tourism Management, vol. 27, no. 5, 925-933.

Kokkranikal, J, Mclellan, R \& Baum, T 2003, 'Island tourism and sustainability: a case study of the Lakshadweep Islands', Journal of Sustainable Tourism, vol. 11, no. 5, pp. 426-447.

Kotler, P \& Caslione, JA 2009, Chaos. Zarządzanie i marketing w erze turbulencji, MT Biznes, Warszawa.

Law, A, Delacy, T \& Mcgrath, M 2017, 'A green economy indicator framework for tourism destinations', Journal of Sustainable Tourism, vol. 25, no. 10, pp. 1434-1455.

Lim, C 1999, 'A meta-analytic review of international tourism demand', Journal of Travel Research, vol. 37, no. 3, pp. 273-284.

McElroy, JL \& Parry, CE 2010, 'The characteristics of small island tourist economies', Tourism and Hospitality Research, vol. 10 , no. 4 , pp. 315-328.

Nowakowska, A 2011, 'Problemy i konflikty rozwoju turystyki' in Turystyka w Polsce w okresie kryzysu, eds A GotowtJeziorska \& K Łopaciński, Polskie Stowarzyszenie Turystyki, Warszawa, pp. 27-43. 
Nunkoo, R, Gursoy, D \& Juwaheer, TD 2010, 'Island residents' identities and their support for tourism: an integration of two theories', Journal of Sustainable Tourism, vol. 18, no. 5, pp. 675-693.

Okumus, F. \& Karamustafa, K 2005, 'Impact of an economic crisis. Evidence from Turkey', Annals of Tourism Research, vol. 32, no. 4, pp. 942-961.

Ostasiewicz, S, Rusnak, Z \& Siedlecka, U 1999, Statystyka. Elementy teorii $i$ zadania, Wydawnictwo Akademii Ekonomicznej we Wrocławiu, Wrocław.

Padilla, A \& McElroy, JL 2005, 'The tourism penetration index in large islands: the case of the Dominican Republic', Journal of Sustainable Tourism, vol. 13, no. 3, pp. 353-372.

Papatheodorou, A, Rosselló, J \& Xiao, H 2010, 'Global economic crisis and tourism: consequences and perspectives', Journal of Travel Research, vol. 49, no. 10, pp. 39-45.

Pizam, A \& Fleischer, A 2002, 'Severity versus frequency of acts of terrorism: which has a larger impact on tourism demand?', Journal of Travel Research, vol. 40, no. 3, pp. 337-339.

Podhorodecka, K 2014, 'Impact of tourist and one-day visitor arrivals on economic growth. Case study of the Cayman Islands', Miscellanea Geographica Regional Studies on Development, vol. 18, no. 3, pp. 16-25.

Podhorodecka, K 2016, 'The impact of the global economic crisis on tourism in Cyprus', Annals of Marketing \& Economics, vol. 2, no. 1, pp. 99-110.

Pratt, S 2015, 'The economic impact of tourism in SIDS', Annals of Tourism Research, vol. 52, pp. 148-160.

Prideaux, B \& Witt, S 2000, 'The impact of the Asian financial crisis on Australian tourism', Asia Pacific Journal of Tourism Research, vol. 5, no. 1, pp. 1-7.

Reddy, MV 2013, 'Global tourism and travel industry: performance during the double dip recession and recommendations for transitions to a green economy', The World Financial Review 14 January. Available from: <http:// www.worldfinancialreview.com/?p=977>.

Repetowski, R 2010, 'Konkurencyjność przedsiębiorstw w dobie globalnego kryzysu finansowego' in Przedsiębiorczość w warunkach integracji europejskiej, Przedsiębiorczość, eds Z Zioło \& T Rachwał, no. 6, Zakład Przedsiębiorczości i Gospodarki Przestrzennej IG UP, Wydawnictwo „Nowa Era”, Warszawa-Kraków, pp. 92-100.

Ritchie, BW 2004, 'Chaos, crises and disasters: a strategic approach to crisis management in the tourism industry', Tourism Management, vol. 25, no. 6, 669-683.

Rucińska, D \& Lechowicz, M 2014, 'Natural hazard and disaster tourism', Miscellanea Geographica Regional Studies on Development, vol. 18, no. 1, pp. 14-25.

Ryan, C 1993, 'Crime, violence, terrorism and tourism: an accidental or intrinsic relationship?', Tourism Management, vol. 14 , no. 3 , pp. 173-183.

Sarışık, M, Sarı, D, Sarı, S \& Halis, M 2011, Tourism sector in order to recovering from the recession: comparison analyses for Turkey. Procedia - Social and Behavioral Sciences, vol. 24, pp. 181-187.

Scheyvens, R \& Momsen, J 2008, 'Tourism in small island states: from vulnerability to strengths', Journal of Sustainable Tourism, vol. 16, no. 5, pp. 491-510.

Scheyvens, R, \& Momsen, J 2008, 'Tourism and poverty reduction: issues for small island states', Tourism Geographies, vol. 10, no. 1, pp. 22-41.

Schubert, SF, Brida, JG \& Risso, WA 2011, 'The impacts of international tourism demand on economic growth of small economies dependent on tourism', Tourism Management, vol. 32, no. 2, pp. 377-385.
Seetanah, B 2011, 'Assessing the dynamic economic impact of tourism for island economies', Annals of Tourism Research, vol. 38, no. 1, pp. 291-308.

Shareef, R \& McAleer, M 2005, 'Modeling international tourism demand and volatility in small island tourism economies', International Journal of Tourism Research, vol. 7, no. 6, 313-333.

Shareef, R, Hoti, S \& McAleer, M 2008, 'The economics of small island tourism', Edward Edgar, Cheltenham.

The Index Mundi Website - detailed country statistics, charts, and maps compiled from multiple sources. Available from: $<$ www.indexmundi.com>. [12 December 2014].

The UN World Tourism Organization Web Site - Tourism Statistics. Available from: <www.unwto.org>. [20 April 2014].

The World Bank Website 2014, Data World Bank. Available from: $<$ www.data.worldbank.org>. [22 April 2014].

Travel \& Tourism Economic Impact 2013 World, 2013, World Travel and Tourism Council. Available from: <www.wttc. org>. [20 May 2015].

United Nations Development Programme - Human Development Reports - Human Development Data (19902015). Available from: <www.hdr.undp.org/en/data>. [5 October 2014].

UNWTO World Tourism Barometer, vol. 8, no. 1, January 2010.

Vanegas, S \& Croes, RR 2000, 'Evaluation of demand: US tourists to Aruba', Annals of Tourism Research, vol. 27, no. 4, pp. 946-963.

Wang, T 2009, 'The impact of crisis events and macroeconomic activity on Taiwan's international inbound tourism demands', Tourism Management, vol. 30, no. 1, pp. 75-82.

Wanhill, S 1994, 'The measurement of tourist income multipliers', Tourism Management, vol. 15, no. 4, pp. 281-283.

Webber, AG 2001 'Exchange rate volatility and cointegration in tourism demand', Journal of Travel Research, vol. 39, no. 4, pp. 398-405.

Wilkinson, PF 1989, 'Strategies for tourism in island microstates', Annals of Tourism Research, vol. 16, no. 2, pp. 153-177.

Winiarski, R \& Zdebski, J 2008, Psychologia turystyki, Wydawnictwa Akademickie i Profesjonalne, Warszawa.

Yeoman, I 2011, 'The changing behaviours of luxury consumption'. Journal of Revenue \& Pricing Management, vol. 10, no. 1, pp. 47-50.

Zdon-Korzeniowska, M \& Rachwał, T 2011. 'Turystyka w warunkach światowego kryzysu gospodarczego', Prace Komisji Geografii Przemysłu, vol. 18, pp. 116-128. 